\title{
ALIRAN SEMPALAN DI KOTA BANJARMASIN (Kajian terhadap Ajaran Abah Pal Lima)
}

\author{
Arni \\ Universitas Islam Negeri Antasari Banjarmasin \\ arnidaily@yahoo.com
}

Diterima 20 Desember 2019 | Direview 25 Desember 2019|Diterbitkan 29 Desember 2019

\begin{abstract}
:
The Sempalan sect taught by Abah Pal Lima has been developing for a long time, with a number of followers of more than seven thousand people scattered across different regions, and its teachings do not have a handbook. People are interested in this teaching because they have advantages such as alternative medicine and other magic powers. Throughout his teachings, he also believes in the presence of God, who has different qualities but does not believe in the foundations of faith and the pillars of Islam. So do not believe in the existence of gods, prophets, holy books (the Koran) as well as the question of taqdir, and there is no duty to worship and not to make prayers, fasting, zakat and pilgrimages. He assumed that besides him and his followers, they were considered heretics and would go to hell. This teaching gives priority to mental problems and believes that they are "inner people" who are in "culture" rather than "born" people in "the world." This is their reason for not carrying out the obligations ordered by Allah Almighty. The teachings of Abah Pal Lima is strongly influenced by the teachings of tasawuf wahdat al-wujud (unity of being) which was developed by Ibn Arabi, because it discusses the problem of Nur Mubammad and in humans, there is an element of divinity in addition to the element of being (al-Haq and al-Khalq). It is also influenced by the teachings of alFarabi on the principle of emanation or delegation. The teaching of Abah Pal Lima was heretically rejected by the Banjarmasin City Ulema Council on 06 Jumadil Awwal 1439 A.D./23 January 2018 AD with a letter-number. 004/DPK-MUI/Bjm/1/1/2018, since the contents of the teachings, are in accordance with the ten criteria for heresy according to the MUI.
\end{abstract}

Keywords: Aliran, Sempalan, Pervert.

Abstrak:

Aliran Sempalan yang diajarkan Abah Pal Lima sudah lama berkembang dengan jumlah pengikut lebih dari tujub ribu orang yang tersebar di berbagai daerah, dan ajarannya tidak memiliki kitab pegangan. Orang tertarik mengikuti ajaran ini karena ada kelebihan yang dimilikinya seperti melakukan pengobatan alternatif dan kesaktian lainnya. Dalam ajarannya masih mempercayai adanya Allah swt., yang memiliki berbagai sifat, namun tidak mempercayai adanya rukun iman dan rukun Islam. Sehingga tidak percaya kepada adanya malaikat, rasul, kitab suci (Alquran) serta masalah taqdir dan tidak ada kewajiban untuk bersyahadat serta tidak melaksanakan salat, puasa, zakat dan haji. Dia beranggapan selain dia dan pengikutnya dipandang sesat dan akan masuk neraka. Ajaran ini mengutamakan masalah batin, dan beranggapan babwa mereka adalah "orang batin" yang berada di "alam" bukan orang "labir yang berada di "dunia". Inilah alasan mereka sehingga tidak melaksanakan kewajiban-kewajiban yang diperintabkan oleh Allah swt. Ajaran Abah Pal Lima ini sangat dipengarubi oleh ajaran tasawuf wahdat al-wujud (kesatuan wujud) yang dikembangkan oleh Ibnu Arabi, karena membicarakan masalah nur Mubammad dan pada manusia ada unsur ketuhanan selain adanya unsur kemakhlukkan (al-Haq dan al-Khalq). Juga dipengarubi oleh ajaran al-Farabi yang berkenaan dengan teori emanasi atau pelimpahan. Ajaran Abah Pal Lima ini divonis sesat oleb Majelis Ulama Kota Banjarmasin, tanggal 06 Jumadil Awwal 1439 H / 23 Januari 2018 M. dengan nomor surat. 004/DPK-MUI/Bjm/1/I/ 2018, karena isi ajarannya sesuai dengan sepuluh kriteria aliran sesat menurut MUI.

Kata Kunci: Aliran, Sempalan, Sesat.

\section{Pendahuluan}


Agama yang diakui oleh pemerintah Indonesia ada enam yaitu: Agama Islam, Katolik, Protestan, Hindu, Budha dan agama Kong Fu-tse. Selain dari enam agama tersebut, ada aliran Kepercayaan atau kebatinan yang disebut Kepercayaan terhadap Tuhan Yang Maha Esa. ${ }^{1}$ Selain enam agama dan Kepercayaan terhadap Tuhan YME., tersebut di atas, ada lagi yang disebut Gerakan Sempalan atau Aliran Keagamaan yang berkembang di tengah masyarakat.

Istilah gerakan sempalan di Indonesia biasanya sebagai sebutan terhadap gerakan atau aliran agama yang dianggap aneh, atau setidaknya menyimpang dari akidah, ibadah, amalan atau pendirian mayoritas umat. Sebagaimana diungkapkan Martin Van Bruinessen, istilah ini agaknya merupakan terjemahan dari kata sekte atau sectarian, sebuah kata yang berkonotasi negatif, seperti protes terhadap dan pemisahan diri dari mayoritas, sikap eksklusif, pendirian tegas tetapi kaku, klaim monopoli atas kebenaran dan fanatisme. Bahkan di Indonesia ada kecenderungan untuk melihat gerakan sempalan ini sebagai ancaman terhadap stabilitas dan keamanan nasional. ${ }^{2}$

Munculnya aliran/paham keagamaan ini merupakan kekayaan budaya, namun tidak jarang juga ada yang menimbulkan keresahan di kalangan masyarakat. Di kota Banjaramasin tepatnya di Kelurahan Pemurus Baru RT. 01, telah berkembang Aliran Keagamaan atau Gerakan Sempalan atau Aliran Sempalan yang diajarkan oleh Mardiansyah. Dari hasil kajian awal ajarannya ini telah meresahkan masyarakat sebab isi ajarannya dipandang berbenturan dengan ajaran Islam, yakni: syahadat, Alquran tidak diperpegangi, salat wajib tidak dilaksanakan karena cukup dengan mengingat Allah, dan murid laki-laki boleh menggauli isteri orang lain.

Adapun judul pada penelitian ini adalah"Aliran Sempalan di Kota Banjarmasin Kalimantan Selatan (Kajian terhadap Ajaran Abah Pal Lima). Penelitian ini mendeskripsikan agar mengetahui keberadaan yang sebenarnya terhadap Aliran Sempalan atau Aliran Keagamaan dengan nama Ajaran Abah Pal Lima yang berkembang di kota Banjarmasin Kalimantan Selatan. Baik yang berkenaan dengan konsep ajaran tentang akidah, ibadah maupun yang berkenaan dengan masalah akidah, ibadah dan masalah tasawuf. Hasil penelitian ini diharapkan dapat memberi informasi yang sebenarnya mengenai keberadaan Aliran Sempalan atau Aliran Keagamaan di kota Banjarmasin Kalimantan Selatan kepada pemerintah, tokoh agama, masyarakat, dalam rangka menambah wawasan pengetan sebagai bahan masukkan kepada instansi terkait yakni PAKEM yang meliputi: - Kepala Kejaksaan Negeri (Ketua). - Kepala Seksi Intelijen Kejaksaan Negeri (Wakil Ketua). Anggotaanggota: Ketua Umum MUI Kota Banjarmasin. - Pasi Intel Kodim. - Kasat Intelkam Polresta. - Kabid Kesbang dan Polinmas Pemerintah Kota. - Kasi Urusan Agama Kementerian Agama Kota. - Organisasi Masyarakat. agar dapat melakukan pengawasan dan pembinaan sesuai aturan.

Lokasi penelitian ini adalah Kelurahan Pemurus Baru Kecamatan Banjarmasin Selatan Kota Banjarmasin Kalimantan Selatan. Subjek penelitian ini adalah, pimpinan atau pendiri Aliran Sempalan, yakni Mardiansyah dan pengikutnya. Sedangkan yang menjadi objeknya adalah isi ajarannya yang meliputi sekitar masalah ketuhanan, ibadah dan hal-hal yang berkaitan dengan masalah tasawuf. Data dan sumber data yang digali dalam penelitian ini adalah terdiri dari data pokok (primer) yaitu data

${ }^{1}$ Kamil Kartapradja, Aliran Kebatinan dan kepercayaan di Indonesia, ( Jakarta: yayasan Masagung

${ }^{2}$ M. Mukhsin Jami, Agama-agama Baru di Indonesia, ( Yogyakarta: Pustaka Pelajar 2008), 142. 
pokok yang diperoleh dari sumber asli. Yakni data mengenai isi ajaran tentang masalah akidah, ibadah dan tasawuf dalam upaya mendekatkan diri kepada Allah dan data pelengkap (sekunder) Data sekunder adalah data pelengkap atau penunjang data pokok yang memuat informasi tambahan mengenai gambaran daerah penelitian.

Sumber data dari Responden adalah mereka yang dapat memberikan informasi data pokok secara langsung kepada peneliti. Mereka itu ialah pimpinan atau pengajar serta pengikutnya. Sedangkan Informan adalah orang yang bekerja pada instansi terkait seperti pihak kepolisian, kejaksaan Tinggi, Himpunan Penghayat Kepercayaan terhadap Tuhan YME. (HPK), RT. MUI., Lurah yang dapat memberi informai tambahan sebagai data untuk menunjang data pokok.

Teknik Pengumpulan data dilakukan dengan teknik-teknik observasi, wawancara dan dokumentasi yakni mengumpulkan dokumen-dokumen sesuai dengan data yang diperlukan kemudian dianalisis dengan teknik analisis deskriptif, kualitatif yaitu setelah data dikumpulkan, direvisi, diklasifikasi, kemudian diuraikan data tersebut sesuai dengan pokok permasalahannya ke dalam uraian-uraian yang disusun secara sistematis.

Sejarah singkat Ajaran Abah Pal Lima.

Aliran yang diajarkan oleh Abah Pal Lima (dengan inisial M.) ini tidak mempunyai nama, namun hanya dikenal sebagai ajaran Abah Pal Lima. Dia sendiri (M) tidak mau dipanggil Ustaz, guru, atau kiai, namun terbiasa dia dipanggil dengan panggilan "Abah/Ayah". Dia lahir sekitar tahun 1949, sebab data yang di dapatkan dia tamat Sekolah Dasar pada 1961. Dia anak keempat dari lima orang bersaudara yakni Lina, Midi, Hadi dan Mila dan M lahir pada urutan keempat. Setelah lulus Sekolah Dasar tak selang beberapa tahun menjadi pedagang ikan keliling., kemudin dia diterima menjadi tentara Angkatan Darat.

Ibu dan Ayahnya asli orang Rantau. Dia bersekolah di Banjarmasin mengikuti ayah dan ibunya yang merantau. Dalam perjalanan hidupnya dikatakan sangatlah susah, karena pernah berjualan ikan. M menjelaskan dalam mencari ilmu untuk kebahagian hidup dia belajar kepada 55 orang guru, namun satu orang pun tidak ada yang sampai ilmunya ke dia, karena dia merasa mendapatkan "ilmu laduni" yang langsung masuk ke batinnya. Hal ini di luar jangkauan dari pemikiran ulama lahir tuturnya. Dalam penjelasannya yang cukup panjang bahwa semua guru yang selama ini dibanggakan dan diikutinya adalah salah atau sesat. Semua guru itu akan hangus jadi tengkorak atau akan masuk api neraka. Pemikirannya ini muncul karena dalam perjalanan hidupnya dia merasa mendapatkan "Ilmu Laduni" itu sehingga dapat mengetahui perkara gaib, dan ilmu inilah yang sekarang diajarkannya kepada pengikut-pengikutnya. Dalam pengakuannya sekarang dia mempunyai 7.000 orang lebih pengikut, dan pengikutnya itu umumnya berasal dari orang-orang yang jauh dari tempat tinggalnya, seperti dari Kalayan, Kuin, Belitung Amuntai, Pelaihari, Terantang, Kaltim, Kalbar, Jawa dan lain sebagainya ${ }^{3}$. Dan pengikut-pengikutnya itu tidak secara serentak hadir dalam setiap menghadiri pengajiannya, karena tempat mereka banyak yang datang dari luar daerah Banjarmasin

Seseorang diakui sebagai anggota atau pengikut apabila sudah dibaiat, dengan menyediakan berbagai perlengkapan berupa gula, pisang, kopi, beras ketan, telor tiga biji. Bila sudah di baiat maka tahu siapa Tuhan, tapi tidak boleh diceritakan kepada 
siapapun, bila diceritakan akan gila. Bila hendak tahu siapa Tuhan maka harus masuk dan mengikuti ajaran ini serta harus dibaiat. Bila sudah dibait tidak boleh lagi salat, puasa, zakat, haji ${ }^{4}$.

Penganut aliran ini menganggap bahwa mereka juga bagian dari umat Islam. Bahkan mereka berkeyakinan hanya ajaran merekalah yang benar, sedangkan ajaran Islam yang diajarkan dari kelompok lain di daerah ini seperti ajaran $\mathrm{KH}$. Zaini bin Abdul Ghani (guru sekumpul), KH.. Ahmad Zuhdiannor dan ulama-ulama lainnya, mereka yakini telah berada dalam kesesatan karena selalu menduakan Allah, sehingga dianggap syirik ${ }^{5}$.

M mengungkapkan bahwa dalam menyampaikan ajaran atau ilmunya kepada pengikutnya, dia mengatakan bahwa tidak ada istilah guru dan murid. Hanya bapapandiran bila benar dariku maka pakai atau terapkanlah dalam kehidupan dan bila ternyata salah dariku, maka buang atau tinggalkanlah ${ }^{6}$. Dan dalam kesehariannya disamping menyampaikan ajarannya kepada pengikutnya, dia juga punya keahlian dalam pengobatan alternatif, sehingga terkadang ada orang yang datang minta bantuannya uantuk mengatasi masalah penyakit atau masalah lainnya ${ }^{7}$.

\section{Pengalaman Spiritual Abah Pal Lima}

Abah Pal Lima mengaku mendapat ilmu laduni. Laduni artinya tiada, yaitu tiada melalui guru, karena ilmu itu datang dengan sendirinya ke dalam batin kita, dan bisa melaui mimpi. Dia mengaku bertemu dengan guru Zaini Abdul Ghani dan Syekh Arsyad al- Banjari, yang sama-sama mengaku ajarannya sesat, dan yang selamat hanya kedua orang tuanya saja. Dia juga mengetahui Bah Hasyim di Basirih juga menjadi tengkorak atau tersesat, karena dua orang muridnya yang menyaksikan pembongkaran kubur Bah Hasyim ternyata hangus jadi tengkorak yang kelak masuk neraka.

Dalam prediksinya Sorgi Mukti di Sugai Jingah diselamatkan sehingga dia tidak hangus. Dan Abu Bakar, Umar bin Khattab, Usman bin Affan, serta Ali bin Abi Thalib adalah orang batin yang juga berada dalam keselamatan. Dan mereka tidak mungkin mengerjakan ihram ataupun haji . Satu-satunya nabi yang bertemu Allah adalah nabi Muhammad. Tp bila dikatakan nabi Muhammad bertemu Allah berarti berdua yang hidup berarti syirik ${ }^{8}$

Dengan ilmu yang dimiliki Abah Pal Lima bisa memberi air doa, sebagai pengobatan alternatif kepada yang meminta bantuannya, termasuk memandikan orang bagi yang ingin kebal dll. Dia mengaku setiap malam Jumat 41 orang wali berkumpul di rumahnya dan bersamanya. Dari perkumpulan itu diberitahukan oleh para wali peristiwa yang akan terjadi seperti dimana akan terjadi musibah gempa, dll. Di antara wali-wali yang datang adalah wali songo, dan wali yang ada di Kalimantan Selatan. Guru Zaini Abdul Ghani di anggap tidak termasuk wali, sebab punya kesalahan menjamin murid masuk sorga lewat musafahah.

Pengikutnya ada yang meninggal dunia sudah satu tahun 3 bulan ternyata setelah kuburnya dibongkar karena kena pembuatan jalan, ternyata badannya masih kuning dan masih utuh beserta tabalanya harum. Dan juga di bongkar kubur murid

${ }^{4}$ Wawancara dengan HAL., tanggal 05 Agustus 2018

${ }^{5}$ Wawancara dengan HAM tanggal 05 Agustus 2018

'Wawancara dengan MAR Tanggal 12 Agustus 2018

${ }^{7}$ Wawancara dengan YUN tanggal 12 Agustus 2018

${ }^{8}$ Wawancara dengan MAH., tanggal 02 September 2018 
yang lain ternyata hanya bau harum sementara tabala dan mayat tidak ada atau menghilang, mereka beranggapan yang meninggal dunia itu sudah masuk sorga Keadaan ini membuat semakin yakin pengikutnya?

MY mengatakan pengikut dari ajaran ini tidak lagi melaksanakan salat. Sari Sumahir seorang janda, yang merupakan murid kesayangan Abah Pal Lima. dikatakannya Sari Sumahir ini telah memiliki ilmu pengasih, yang diperoleh dari gurunya, shingga MY sangat tergila-gila kepadanya, dan tidak sedikit sudah harta yang kuserahkan kepadanya, tuturnya. Dan setiap hari MY mengaku memberi uang paling sedikit 40 ribu setiap hari, dan membelikan Hp senilai 3 juta tuturnya. Sangat bersemangat dia menerangkan apabila Sari Sumahir mau sesuatu apa saja dariku, maka aku selalu berusaha mengadakannya, dan tidak bisa menolaknya. Padahal aku sadar bahwa dia bukan isteri atau pacarku tutur MY sambil menitis air matanya. Dulu aku cukup banyak punya harta, tapi kini sudah semakin berkurang gara-gara kasihan dengannya, sehingga selalu menanggung biaya hidupnya, sebab dia tidak bekerja. Namun dia memiliki ilmu pengasih dari gurunya dan aku tidak bisa lari darinya. Hal ini disebabkan kesaktian dari gurunya yaitu Abah Pal Lima. Lebih jauh dikatakannya Sari Sumahir ini satu rumah dengan Eka, dan kedua orang ini telah mengikuti ajarannya atas bujukan $\mathrm{Hj}$. Fauziah, yang telah lebih dulu mengikuti ajaran itu $^{10}$.

HAL., juga mengakui kehebatan Abah Pal Lima, yang dianggapnya punya keramat, yaitu di saat HAL ikut ziarah bersama rombongannya, ke makam yang di anggap keramat, di antaranya makam Abdul Hamid Habulung di daerah Martapura. Semua penziarah menggunakan perahu kecil (jukung) menuju ke makam yang berada di seberang sungai, sementara Abah Pal Lima dilihat oleh pengikutnya menyebarangi sungai Martapura itu dengan berjalan kaki di atas air sungai menuju makam tersebut. Dan Abah Pal Lima mengatakan kepada pengikutnya bahwa datu Habulung menjemputnya dengan mengulurkan tangannya ke sungai ${ }^{11}$.

\section{Isi Ajaran Abah Pal Lima}

Abah Pal Lima mengatakan bahwa orang yang beragama Islam wajib mengatakan dua kalimat Syahadat:

$$
\text { اشهُ ان لا اله الا الله . . واشهد ان خحما رسول الله }
$$

Dia mengatakan siapa saja yang mengucapkan dua kalimat syahadat itu, maka dikatakan oleh ustaz, kiai, habib ataupun tuan guru, bahwa orang yang telah mengucapkan dua kalimat syahadat itu telah beragama Islam. Namun sebenarnya mereka tidak menyadari, bahwa mereka telah memakai syahadat orang lain, sebab ucapan:

$$
\text { اشهد ان لا اله الا الله }
$$

syahadat ini, sebenarnya hanya Allah yang memilikinya. Kemudian syahadat yang berikutnya adalah :

$$
\text { واشهد ان خحما رسول الله }
$$

Syahadat ini, hanya Muhammad yang memilikinya. Dan ternyata syahadat untuk ustaz, kiai, habib, ataupun tuan guru serta pengikutnya tidak ada. Ini berarti ustaz, habib, kiai, ataupun tuan guru itu belum atau tidak beragama, karena

${ }^{9}$ Wawancara dengan MH., 5 Agustus 2018

${ }^{10}$ Wawancara dengan MY., tanggal 12 Agustus 2018

${ }^{11}$ Wawancara dengan HAL., tanggal 05 Agustus 2018 
syahadatnya itu punya orang lain yaitu Allah dan Muhammad. Abah Pal Lima mengaku dia dan pengikutnya adalah "orang batin" dan tdak punya syahadat. Lebih jauh dijelaskannya kami sebagai orang batin sebenarnya kami adalah mati, sebab kalau masih mengaku hidup dan Allah hidup berarti ada dua yang hidup, maka hukumnya syirik. Oleh karena itu kita harus meyadari bahwa sebenarnya kita adalah mati. Kita bagaikan kepompong yang tidak bergerak. Kita ini berada di alam syahadah dan jin berada di alam maukit, malaikat di alam malakut, hamba di alam jabarut dan Allah berada di alam lahut, hamba rahasia Allah, manusia rahasia jin. Banyak ulama seperti guru Zaini Ghani jadi hangus dan H. Bakri jadi tengkorak, kurang apa amal ibadahnya, salat, zikir dan salawatnya sangat banyak, salahnya karena mereka mengaku hidup, sehingga ada dua yang hidup yaitu Allah dan dia, sehingga hukumnya syirik.

Allah berkata aku tidak pernah memandang amal ibadahmu, salat, puasa, zakat dan hajimu, kecuali batinmu yang sempurna. Sifatku jar Allah la baula wa la kuata illa billabil aliyil azim : " bahwa sifatku lemah gaib kuatkan, kuasaku, melainkan kuat kuasaku, bahwa tidak satupun gerak kecuali gerakku, pantaskah Allah memerintahkan salat, puasa haji kepada kita padahal ini berarti Allah memerintahkan kepada diri sendiri, karena kita adalah mati, kita bagai kepompong yang tidak bergerak.

Kita dalam hidup harus kamalul yakin, bukan yakin saja. Yakin milik manusia, ainal yakin milik jin dan haqul yakin milik malaikat. Kamalul yakin sifat-Ku yang sempurna ${ }^{12}$.Kita Percaya bahwa qodrah kuasa Allah, iradat kehendak Allah, Ilmu, ilmunya Allah, hayat hidupnya Allah, Sama' mendengar Allah, rasa melihat Allah, kalam, kata-kata Allah. Tidak ada yang kita miliki disitu. Lebih jauh dikatakannya, bahwa dia dan pengikutnya adalah "orang batin" yang tidak mengaku hidup. La haw lawala. Tidak adil Allah kalau memerintahan salat kepada orang yang mati.

Pembahasan yang berhubungan dengan kalam Ilahi, dikatakan bahwa Alquran sebagai kalam Allah itu tidak benar bagi "orang batin", sebab kalau kita letakan di atas meja dia tidak bisa berbunyi (bersuara). Kalau memang bisa berbunyi betul itu kalam Allah. Sedangkan bagi "orang lahir", Alquran itu memang benar kalam Allah. Dalam Alquran ada "Hudallinnas" (petunjuk bagi manusia). Kalau sebagai petunjuk berarti manusia tidak selamat. Allah berkata Alquran itu petunjuk sifat-Ku. Sudah jelas jar Allah jangan diduakan hidup-Ku. Bila menduakan hidup-Ku tunggu azab-Ku di neraka nanti. Dikatakannya bahwa Alquran itu baginya hampir sdh di luar kepala, sekarang baca surat yasin saja tidak bisa lagi, sudah lupa setelah mendapat "ilmu Laduni“

Penganut aliran ini tidak percaya dengan kitabullah yaitu Alquran dan Hadits nabi. Mereka menganggap bahwa Alquran dan Hadits itu adalah buatan manusia, jadi kalau percaya dengan Alquran dan Hadits Rasulullah saw. adalah musyrik ${ }^{13}$. Memang M mengkritik serta mengubah isi kandungan Alquran, seperti surah Adzdzaariyat ayat 56 yang isinya adalah: "Tidak Ku-ciptakan jin dan manusia kecuali untuk beribadah kepadaku”. Ayat ini kemudian mereka kritik bahwa seharusnya isinya adalah: "Tidak Kuciptakan jin dan manusia kecuali untuk menyembah sifat-Ku".

Lebih jauh dikatakannya bahwa kita percaya bahwa qodrah berarti kuasa Allah, iradat berarti kehendak Allah, Ilmu berarti ilmunya Allah, hayat berarti hanya Allah

12Wawancara dengan MAR, 12 Agustus 2018

${ }^{13}$ Wawancara dengan MAR., 12 Agustus 2018

${ }^{14}$ Wawancara dengan MAR, tanggal 19 Agustus 2018 
yang hidup, sama' Allah yang mendengar, rasa melihat Allah, kalam, berarti kata-kata Allah. Tidak ada yang kita miliki dari sifat-sifat Allah itu, Sebagai "orang batin" kita adalah mati yang tidak ada kuasa, kehendak, ilmu, hidup, serta tidak mendengar ataupun berkata-kata.

Allah berkata dengan jujur: "inna lillah wa inna lillabi rajiun" Asal kamu datang dari Allah, kembalilah kamu kepada Allah tidak ada dikatakan kembali ke sorga, berarti ulama-ulama bohong selama ini. Yang mengakatakan kita akan masuk sorga, karena ulama berbohong dan menduakan Allah, sehingga banyak sekali ulama, habib atau syekh yang masuk neraka. Sedangkan kami "orang batin" atau "orang alam" bukan "orang dunia" tidak demikian.

Dalam agama ada kalimat La ilaha illallah. Ini tentang sifat Allah. La artinya bulu kulit, ilaba berarti darah daging, Allah berarti otak, kamu tidak memiliki kecuali milik-Ku jua kata Allah. Allah tidak mempunyai hurup dan suara itu kenyataan yang sempurna. Semua ulama sampai kepada nabi sesat semua. Jar Allah barang siapa yang menduakan hidup, tunggu azab-Ku di neraka nanti. Dunia ini hanya tipuan, dan bagi kami orang yang mengaku mati tidak ada lagi amalan. Mati syariat hancur lebur tinggal tengkorak, mati tarekat kurus kering, mati hakikat putih kuning, dan mati makrifat raja'. Kalau kita ziarah ke kubur, hendaknya kita diam saja jangan ada yang dibaca, sebab kalau ada yang dibacakan, maka yang didalam kubur semakin dipukupi atau diazab.

Ketika pembahasan yang berberhubungan dengan nabi Muhammad, dikatakannya bahwa Muhammad bukan utusan Allah, sebab kalau utusan Allah berarti ada dua yang hidup, ini artinya syirik. Serta kalau kita yakin nabi menerima wahyu, berarti nabi itu hidup, kalau ada dua yang hidup berarti juga syirik, dan nabi Muhammad itu berada dalam kesesatan, termasuk wali songo (Sunan Gresik, Sunan Ampel, Sunan Bonang, Sunan Drajat, Sunan Kudus, Sunan Giri, Sunan Kalijaga, Sunan Muria, dan Sunan Gunung Jati) yang ada di pulau Jawa, juga sesat semuanya, yakni jadi tengkorak karena semua matinya dibakar oleh api neraka. Hal ini sebabkan mereka telah syirik ${ }^{15}$

Semua ulama, syekh mengajarkan agar takwa kepada Allah dan jangan berubah, anjuran itu hanya berlaku bagi manusia sebagai orang lahir. Lain halnya kami sebagai "orang batin" atau "orang mati" tidak ada yang ditakuti, kamupun tidak percaya kepada adanya munkar nakir. Bagi orang batin tidak dicabut ruhnya, tidak ditanya munkar nakir dan tidak ada siksa kubur. Bagi orang batin malaikat itu tidak ada. Orang yang mengatakan adanya malaikat itu hanya pemberitahuan dari ulama, dan itu benar bagi orang dunia atau manusia. Ulama tidak bisa menyelamatkan kita, sebab ulama semua diazab masuk dalam neraka 500 tahun sebelum kita.

Ada cerita Sugi namanya: 30 hari disuruh gurunya mehalwat di kubur, bila sudah selesai apapun yang dikehendaki akan terjadi. Lalu di lakukan Sugi setelah sampai 21 hari dengan menggunakan alat senduk yang bila dibunyikan senduk berarti tidak kuat lagi, dan isterinya yang menjaga di atas kubur. Ternyata Sugi hanya bisa bertahan dalam kubur selama 21 hari, kemudian keluar dari kubur yang dibantu orang lain karena tubuhnya lemah, selama 15 hari setelah keluar dari kubur dia hanya bisa makan bubur. Kemudian setelah segar, dia bercerita waktu dalam kubur dia mendengar suara yang orangnya tidak nampak, kemudian berkata kepada Sugi, kamu 
jangan salat, di alam nyata tidak ada rukun Iman dan tidak ada rukun Islam, syahadatpun tidak ada, Hai Sugi apakah kamu hendak melihat isi neraka ? ya kaya Sugi aku ingin melihat isi neraka. Setelah diperlihatkan ternyata isi neraka itu banyak habib dan ulama karena mereka itulah yang membinasaan sifat-sifat-Ku. Kejadian ini diceritakannya kepada banyak orang, sehingga Sugi dikatakan sesat, karena tidak percaya adanya rukun iman dan rukun Islam. Kemudian pengalaman spiritualnya ini diceritakannya kepadaku kata Abah Pal Lima, dan aku langsung membenarkan bahwa rukun iman dan rukun Islam itu tidak ada. Kata Sugi dari 250 orang guruku, semua tidak membenarkan menganggapku ( Sugi ) tersesat, hanya Abah Pal Lima saja yang membenarkan bahwa rukun iman dan rukun islam itu tidak ada.

Dia lebih jauh mengatakan sifat kami ini adalah mati semua, dan awal kehidupan kami setelah berpulang kerahmatullah, adalah kekal bersama Allah. Hari kiamat itu tidak ada, dan yang mengatakan adanya hari kiamat itu adalah dusta dari ulama, termasuk juga tidak benar yang dikatakan ulama nanti di padang mahsyar mata hari satu jengkal dari kepala, dan kita ditanya ketika meninggal dunia, yakni berapa salat dan puasa kamu, namun dalam talqin terhadap orang mati tidak ditanyakan tentang salat dan puasa itu, yang ada adalah "Kullu Nafsin za atul maut" (inilah mati kamu yang sebenarnya), Bila hayat pasti ada kematian. Cara berpikir ulama seperti itu, karena ulama adalah orang dunia, sedang bagi kami "orang batin" masalah kiamat, keadaan di mahsyar, itu tidak benar adanya. Masalah dosa bagi "orang batin" sebesar apapun dosa diampuni dan masalah syirik sekecil apapun tidak diampuni. Lebih jauh Mardiansyah mengatakan coba pikir kata ulama kalau kamu mau jalan ke sorga, silahkan kamu ke mesjid dan kalau kamu ingin jalan menuju neraka silahkan ke Pambatuan (tempat zina). Tidak ada ulama, habib, atau syekh yang mengatakan kalau kita ke Pambatuan (tempat zina) itu syirik. Itu dosa besar, Kata Allah sebesar apapun dosamu Aku ampuni kalau kamu minta ampun. Mereka tidak sadar kalau di mesjid orang selalu berdoa. Padahal kalau berdoa itu syirik, karena bila berdoa berarti ada yang meminta dan ada yang memberi, ini berarti ada dua, maka syirik, dan ternyata dibantu, disanjung oleh ulama, sementara orang yang pergi ke pembatuan (tempat zinah) selalu dicaci maki oleh ulama. Bagi kami "orang batin", bila melakukan zina itu masih di ampuni tapi yang syirik di mesjid itu tidak diampuni. Sejak kita lahir hingga umur 7 tahun kita masih berada di alam, bila kita bercermin, mengaku aku hebat berarti berada di dunia dan kita tertipu. Dunia tempat tipu daya manusia, dan neraka jahanam tempatnya bagi orang yang tertipu ${ }^{16}$

\section{Ajaran Ibadah Abah Pal Lima}

Dalam agama sudah tentu memiliki adanya perintah yang wajib untuk dilaksanakan serta adanya larangan-larangan yang harus ditinggalkan, jika dilanggar akan mendapatkan sebuah ganjaran sesuai dengan perbuatanya. Dalam hal ibadah $\mathrm{M}$ memberikan sebuah penjelasan bahwa jika orang melakukan hal ibadah maka dia yang melakukan ibadah seperti salat, puasa, haji dan lainnya, maka dia akan mendapat ganjaran hangus terbakar ketika di kubur, alasanya dia mengatakan: "kalau ditelaah kata tidak ada daya dan upaya bagi manusia melainkan kuasa Tuhan, lantas kalau manusia tidak ada daya dan upaya maka pantaskah Tuhan yang Maha Kuasa memerintahkan salat, zakat, haji, kepada kita, tentu tidak pantas dan tidak adil. 
Menurutnya selama ini manusia banyak yang salat hanyalah menyembah kiblat saja. Dan mereka bila dalam keadaan wudu, kemudian membuang angin (kentut) mereka menganggap batal wudunya. Kenapa, harus batal yang membuang angin dari bagian bawah (dubur), sedangkan yang mereka cuci adalah wajah, tangan, kepala dan kaki. Selain dia mengatakan ulama-ulama yang rajin ibadah itu akan hangus terbakar seperti: Datu Kelampaian, Guru Sekumpul, dan ulama-ulama besar lainnya. Dia anjurkan kepada pengikutnya agar tidak melakukan salat karena salat tersebut memiliki sebuah kesalahan besar, yang mana akan membawa manusia kepada kehangusan dan tidaklah akan mendapatkan sebuah keselamatan jika manusia sudah berada pada tahap tersebut, karena dikatakan oleh mereka jika mereka hangus di dalam kubur maka sudah tentu dia akan mendapat siksaan api di neraka nanti ${ }^{17}$

Lebih jauh dikataknnya dia berguru kepada habib, dan mengamalkan salat tahajjud selama tiga tahun, sampai dahiku katanya berciri hitam seperti uang logam. Bila aku meminta kepada Allah bila tidak menagis, maka mataku disapukan bawang supaya keluar air mata, ini perintah habib. Dan aku selalu puasa setiap hari Senin dan Kamis, selama tiga bulan, mulai bulan Rajab, sya'ban dan bulan Ramadhan. Dulu aku sudah terbiasa dengan ibadah, jika aku mati saat itu maka jadi tengkorak atu hangus tubuhku dibakar api neraka, karena aku bukan orang batin saat itu.

Oleh karena itu kami sebagai orang batin harus meyadari bahwa sebenarnya kita adalah mati dan tidak puya kekuatan, La haw lawala. Tidak adil Allah kalau memerintahkan salat, puasa, zakat, haji kepada orang yang tidak punya kekuatan ini. Dalam agama Islam disebutkan ulama satu kali tidak salat, maka selama 500 tahun akan terpanggang disiksa di neraka. Kenapa kita percaya yang seperti ini. Tidak ada ulama yang mengatakan bahwa satu kali kamu salat, maka selama 500 tahun kamu berada di sorga.

Salat, zakat, haji itu hanya untuk orang dunia atau zahir saja. Sedangkan bagi orang batin berkeyakinan bahwa itu tidak benar. Orang batin adalah orang yang menganggap dia tidak hidup serta tidak punya daya, maka tentu tidak akan bisa mengerjakan salat, haji, zakat dll. Allah berkata Aku tidak pernah memandang amal ibadahmu, salat, puasa, zakat dan hajimu, kecuali batinmu yang sempurna.

Bila manusia meninggal dunia sebagai orang zahir, dia wajib dimandikan, diwudui, dikafani, disalatkan, tapi bila dia masuk "dunia batin" boleh dimandikan tapi jangan campur kapur barus, dan jangan diwudukan, kiyamkan, disalatkan, ditalqinkan, serta jangan diarwahi. Kita yang berpulang ke rahmatullah dikatakan Allah antal mautu kablal mautu: (matikanlah dirimu sebelum kamu mati). Asal datang kita dari Allah maka kembalilah kepada Allah. Dan Allah tidak memandang kesempurnaan ibadah kita seperti syahadt, salat, puasa, zakat dan haji, sehingga tidak berguna amal ibadah seseorang seperti salat, puasa, zakat dan hajimu itu, Jadi yang dipandang Allah itu hanya batin yang sempurna.

Allah mengatakan bahwa tanah haram itu adalah masjidil haram, kenapa didatangi untuk berhaji, salat disana padahal haram kata Allah. Oleh karena itu katanya dia tidak mau naik haji padahal sudah dua kali ditawari haji plus oleh pengikutnya dan kalau umrah sudah puluhan kali ditawari selalu ditolak. Sampai 5 juta diletakan uang di depannya untuk biaya umrah, tetap ditolak tuturnya. Sebab bila aku mengambil uang itu katanya sama saja aku bersedia untuk berangkat umrah ke 
tanah haram. Yang berkaitan ibadah haji ini, Menurutnya dalam ibadah haji itu ada orang berihram, dan pengertian dari ihram itu adalah tercengang-cengang diriku tidak tahu akan Tuhan-ku, tidak tahu akan sifatku, siapa aku yang sebenarnya.

Masalah salat. Allah berkata: Fainnama tuwallu Fasamma wathullah: baik di Timur di Barat, atau di mana pun kamu menghadap di situlah ada wujud Allah, orang yang salat hanya menghadap ke kiblat itu salah, maka itu mereka bila meninggal dunia akan menjadi tengkorak semua atau akan hangus dibakar di api neraka. Kita yang dikatakan tidak berdaya upaya tidak adil kalau diperintahkan salat. Menyuruh salat itu hanya perintah ulama, Kita jangan percaya kepada ulama. Ilmu fiqh, tauhid, tasawuf. Syariat, tarekat, hakikat dan makrifat, adalah diajarkan Muhammad yang diwariskan kepada ulama semua tidak benar adanya ${ }^{18}$. Dan anggotanya tidak wajib salat lima waktu, mandi junub, mandi jenazah serta orang meninggal dunia dalam ajaran Mardiansyah tidak wajib disalatkan terbukti. Saudaranya yang meninggal dunia, kaum muslimin sudah menunggu di mesjid mau menyalatkan ternyata kata $\mathrm{M}$ langsung saja dikuburkan, orang-orang pada bingung, dan berkata supir mobil ambulan, "napa kada disembahyangkan orang mati".

Manusia ini mati dia bagai kepumpung yang tidak bergerak, tapi isinya Tuhan. Oleh karena manusia ini, maka tidak ada kewajiban baginya dan kalau kita ini hidup maka ada dua yang hidup berarti syirik. Ajarannya diakui langsung dari Tuhan. Semua yang ada di alam ini milik Allah, maka boleh di ambil atau dimiliki seperti isteri orang lain boleh ${ }^{19}$.

\section{Ajaran Tasawuf Abah Pal Lima}

Dalam masalah tasawuf dia memiliki sebuah pemikiran bahwa mereka mementingkan kepentingan batin dan menjauhi segala kepentingan di dunia guna menuju Allah dan sangat berbeda dengan ajaran tasawuf pada umumnya yang mengutakan batin juga namun tidak mengabaikan syariat seperti salat, puasa zakat dan haji. Lainnya halnya dengan ajaran Abah Pal Lima ini, yang hanya mengutamakan batin. Dia sama sekali tidak menggunakan ibadah lahir, sebagai media mendekatkan diri kepada Allah karena merasa diri bagai kepompong dan isinya tak lain adalah Dia atau Allah itu sendiri, hal ini terungkap dari penjelasannya: "Sifat Allah jangan dirampas, Hayat hidup Allah, Hayun hidup Allah, kita ini mati tidak hidup. Yang hidup itu hanya Allah. Aku lebih nampak dari pada sifat-Ku. Inilah yang masuk ke dalam raga atau rangka. Allah itu wajib ada, wujud artinya ada, mustahil artinya tiada. Aku atau Zat masih asma. Yang benar adalah kita harus mati, yakni mati dalam hidup".

"Orang batin" atau "orang alam" tidak percaya adanya wali. Adanya wali hanya dipercaya oleh orang dunia atau manusia. Orang dunia mengunakan ilmu zahir, sedangkan "orang batin" atau "orang alam" menggunakan ilmu batin. Allah tidak memandang yang zahir, tapi hanya memandang yang batin. Oleh karena itu sangat banyak orang-orang yang tersesat, yaitu orang-orang zahir. Melihat Allah bukan Abah (aku/kita), tapi Aku yang memandang Allah itu. Allah mengatakan basyar melihat Allah, bukan dengan mata. Kalau dengan mata itu syirik. Sama' atau mendengan Allah bukan dengan telinga, kalam atau kata-kata-Ku, bukan dengan mulut, ini tidak bisa. Kalau tidak Aku. Aku berkalam melalui sifat-Ku, bukan sifat yang berkalam ${ }^{20}$

${ }^{18}$ Wawancara dengan MAR., tanggal 2 September 2018

${ }^{19}$ Wawanvara dengan HAL., Tanggal 30 Agustus 2018

${ }^{20}$ Wawancara dengan MAR, tanggal 02 September 2018 
Tokoh yang berkaitan dengan tasawuf (sufi) sekaligus guru asli tasawuf menurutnya adalah Junaid al-Bagdadi juga termasuk golongan orang yang hangus atau kelak masuk dalam neraka, sebab selain dia, juga muridnya, maka seluruhnya akan masuk nereka. Jalan menuju Allah bukan lewat perantara nabi Muhammad melainkan akal yang dimiliki. Maka dari itu Alquran dan hadis adalah sumber ajaran yang tidak penting bagi "orang batin" sebab mendapatkan sumber ajaran hanya dari akal.

Masalah syariat khusus untuk manusia, tarikat adalah pakaian syekh Seman, hakikat khusus untuk orang yang duduk di Muhammad dan makrifat itu yang sempurna. Hakikat tidak pernah sempurna kalau tanpa makrifatullah. Syariat, tarikat, hakikat dan makrifat tidak ada imam, tapi kalau, tasawuf ada imamnya. Bagi penganut batin tidak ada imamnya. Untuk mendapatkan ilmu lahir mudah saja, munngkin sekitar 500 meter kita berjalan, sudah menemukan, tapi ilmu batin seribu kilometer kita mencari belum tentu menemukannya.

Pembicaraan mengenai nur Muhammad diterangkannya bahwa Nur Muhammad itu ada empat yaitu: Muhammad awal, Muhammad Akhir, Muhammad Zahir dan Muhammad Batin. Muhammad Awal adalah Nurku, Muhammad Akhir adalah Ruhku, Muhammad Zahir adalah tubuhku dan Muhammad batin dalam wujud kita bila kita bisa rasakan Muhammad, maka Allah berkata rasakan nur Muhammad dalam wujud kamu, sama halnya engkau merasakan Allah di dalam diri kamu.

Disisi lain Allah mengatakan " ya Muhammad jadinya engkau itu karena nur zat-Ku alam semesta ini terjadi karena nur Muhammad", ini yang diperpegangi ulama, dan sebenarnya pernyataan ini adalah salah, yang benar adalah "Ya Muhammad alam semesta ini karena Nur zat-Ku jua, engkau itu sifat-Ku yang kuberi nama Muhammad". Zat adalah asma saja, Nur artinya hidup bukan cahaya. Maka dikatakan "ya Muhammad engkau tercipta dari nur zat-Ku", maka ini nur berarti hidup. Orang yang memiliki "ilmu batin" merasa duduk di "Alam", sedangkan orang yang ilmu zahir duduk di dunia. Alam semesta ini adalah Allah dan Allah adalah Alam dan Alam adalah Aku. Dan jangan handak ke sorga, sebab bagi "orang batin" sorga tidak pernah benar adanya. Dan bagi "orang batin" dunia itupun tidak ada. Manusia berdiam di dunia sedangkan bagi kami "orang batin" berdiam di Alam. Dunia tidak pernah diciptakan Allah. Yang diciptakan hanya alam semesta (sekalian alam) dari nur zat-Ku juga. Ayat berkata: al-insanu fibi wasiri wa sifati wa gairibi, bermula insan itu rahasia-rahasia-Ku, sifat-sifat-ku tidak lain dari pada Aku. Wafi anfu sikum afala tubsyirun : tidakah engkau memperhatikan Aku ada di dalam diri kamu, penjelasan ini terdapat dalam kitab barincung

Hayat tidak bisa tahayun, maka Allah tidak pernah menghidupkan hayat, kecuali hayun yang maha hidup. Setiap hidup pasti mati. tapi bila sudah "Hayyun" (maha hidup), tidak ada kematian lagi, karena sudah mati. "Antal mautu qablal mautu" (matikalah dirimu seblum kamu mati).

Dialog Abu Bakar dengan Muhammad, bagaimana kita ya Muhammad. kata Muhammad kita la haulawala kuata illa billah, kita tidak bisa bergerak kecuali gerak Allah. Kata abu Bakar kalau begitu kita berati mati, ya mati kata Muhammad. Pesanku kata Muhammad kepadamu jangan percaya kepada yang lain bila percaya kepada yang lain selain Allah, maka kamu syirik. Setelah Muhammad meninggal maka timbulah pelajaran tauhid, fikih dan tasawuf. Untuk ilmu fikih imamnya empat yaitu, Hanafi, Hambali, Maliki, Syafi'i dan untuk ilmu tauhid imamnya dua orang 
yaitu Asy'ari dan Maturidi, dan untuk tasawuf imamnya adalah Junaid al-Bagdadi. Disini orang berimam Syafi'i. Bila kamu berimam berdua, berarti bertiga yang hidup. Hidup Allah jangan dirampas. Jar aku lebih nampak Aku dari pada sifat-Ku ini. Tidak ada Aku (Allah) tidak ada kalian semua. Kita semua adalah sifat Allah dan kembali kepada Allah. Sesuai dengan ayat inna lillah wa inna lillahi rajiun.

Wali itu artinya wakil. Allah Yang Maha Kuasa tidak membutuhkan wakil itu. Tidak kuasakah Allah maka perlu diwakili. Oleh karena itu wali juga sebenarnya tidak ada bagi "orang batin" 21

\section{Tasawuf Yang Mempengaruhi.}

Dalam ajaran Abah Pal Lima banyak dipengaruhi ajaran tasawuf falsafi yaitu dibicarakannya mengenai nur Muhammad diterangkannya bahwa Nur Muhammad itu ada empat yaitu: Muhammad awal, Muhammad Akhir, Muhammad Zahir dan Muhammad Batin. Muhammad Awal adalah Nurku, Muhammad Akhir adalah Ruhku, Muhammad Zahir adalah tubuhku dan Muhammad batin dalam wujud kita bila kita bisa rasakan Muhammad, maka Allah berkata rasakan nur Muhammad dalam wujud kamu, sama halnya engkau merasakan Allah di dalam diri kamu.

Kalau dalam Alquran tidak ada satu ayat pun yang membicakan nur Muhammad. Sementara orang yang tidak mengerti, ada yang menafsirkan kata "nur" dalam ayat 15 surat Al-Maidah sebagai "Nur Muhammad". Ayat tersebut berbunyi"

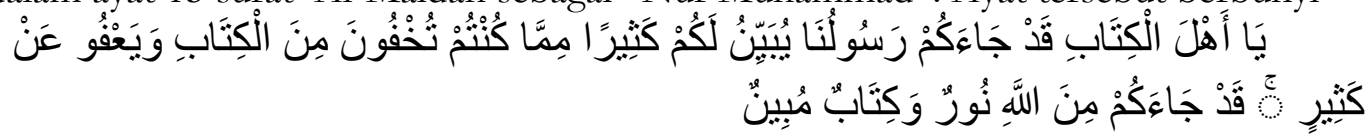

Kata "nur" dalam ayat ini, oleh ahli-ahli tafsir, ditafsirkan sebagai "Muhammad saw." dan ada juga yang menafsirkan sebagai "Al-Islam" dan bahkan ada yang menafsirkan sebagai "Alquran". Kata "nur"yang ditafsirkan sebagai "Muhammad saw" itulah yang kemudian ditafsirkan lebih jauh, bahwa yang dimaksud "nur" dalam ayat itu adalah "nur Muhammad".

Penafsiran yang demikian adalah salah, sebab yang dimaksud dengan "Nur Muhammad " adalah cahaya dalam arti hakiki/hissi, yakni cahaya yang sesungguhnya, sedangkan kata "nur" dalam ayat tersebut adalah dalam arti majazi/kiasan. Jadi penfsiran yang benar, kalau dikembalikan kepada bentuk tasybih (sebab asal Isti'arah adalah tasybih), maka berbunyi demkian:

"Telah datang kepada kamu, dari Allah, (Muhammad saw., yang seperti) nur/cahaya,",

Maka jelas, bahwa ayat 15 dari surat Al-Maidah ini tidak membicarakan tentang "Nur Muhammad". Ayat kedua yang diduga sebagai dalil adanya "nur Muhammad" yang pernah berpindah-pindah dari sulbi ke sulbi nabi-nabi ialah firman Allah, ayat 19 pada surat As Syu'ara, yang berbunyi:

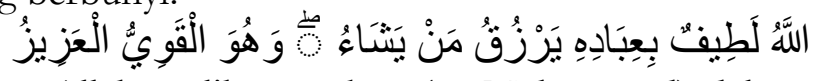

Ayat ini diartikan bahwa Allah melihat engkau (ya Muhammad) dalam sulbisulbi (Punggung) para muwahbidin (ahli tauhid). Penafsiran seperti ini lemah dan salah. Lemah karena sandarannya dari riwayat-riwayat yang lemah (da'if), dan salah karena menyalahi Ulumul Qur'an dan ilmu Bahasa, dengan landasan yang lemah pula ${ }^{22}$.

Ajaran Abah Pal Lima mengenai 'Nur Muhammad" ini dipengaruhi oleh teori emanasi/pancaran yang dikemukakan oleh Al-Farabi. Al-Farabi berkeyakinan bahwa falsafah tak boleh dibocorkan dan sampai ke tangan orang awam. Oleh karena itu

${ }^{21}$ Wawancara dengan M.AR., tanggal 12 Agustus 2018

22 A., Manan, Imran, Pelbagai Masalab Taubid Populer, Jilid I, Surabaya, PT. Bina Ilmu 198 h.258 
filosof-filosof harus menuliskan pendapat-pendapat atau falsafat mereka dalam gaya bahasa yang gelap, agar jangan dapat diketahui oleh sembarang orang, dan dengan demikian iman keyakinnannya tidak menjadi kacau, sebab bila sampai ke orang awam imannya bisa menjadi kacau ${ }^{23}$

Teori emanasi sering disebut sebagai teori urut-urutan wujud. Yaitu tentang keluarnya seuatu wujud yang mungkin atau makhluk dari Dzat yang wajib wujud-Nya atau Zat yang mesti adanya yaitu Tuhan. Al-Farabi mencoba menjelaskan bagaimana yang banyak (makhluk) bisa timbul dari Yang Satu (Esa), tidak berubah, jauh dari benda, karena Akal yang merupakaan substansi Tuhan tidak memerlukan benda, jauh dari arti banyak, karena Tuhan itu Tunggal adanya, Maha Sempurna dan terlepas dari sesuatu yang lain. Berpijak dari keyakinan bahwa Tuhan adalah Akal yang berpikir itu timbul suatu keadaan yang lain dari diri-Nya.

Sebenarnya, pemikiran Al-Farabi ini mengambil pendapat Aristoteles. Menurut Aristoteles, Tuhan adalah Akal yang berpikir. Kemudian untuk menjelaskan terjadinya makhluk dipinjamlah teori emanasi ciptaan Plotinus. Hal ini dikemukakan Drs. H. Hasbullah Bakry SH. Dalam soal kejadian alam dan bagaimana hubungan anatara Khalik dan makhluk, Al-Farabi seperti juga Al-Kindi menyetujui teori emanasi Neo Platonisme. Bahkan lebih jauh dari Al-Kindi, Al-Farabi lebih memperinci teori emanasi yang dinamakannya nadzaratul Faidh (teori pelimpahan) itu dengan menguaraikan sendiri.

Menurut Al-Farabi, segala sesuatu keluar dari Tuhan, karena Tuhan mengetahui zat (substransi) Nya. Ilmu-Nya tersebut telah menjadi sebab bagi sesuatu yang mungkin adanya. Teori emansi ini lahir dilatar belakangi oleh pertanyaan tentang bagaimana alam yang materiil dan beragam ini bisa tercipta dari Allah yang Esa dan immateri. Maka di sinilah Al-Farabi mencoba menjelaskan proses penciptaan tersebut dengan teori emanasi atau yang disebut dengan proses pelimpahan. Jadi menurutnya alam ini tidak lahir secara langsung melainkan melalui proses pelimpahan atau uruturutan wujud. Di sinilah Allah berperan sebagai akal ( akal murni), aqil (yang berpikir tentang diri sendiri), dan ma'qul ( karena merupakan objek yang dipikirkan akal-akal hasil proses pelimpahan ). Lebih jelasnya proses emanasi/pelimpahan tersebut adalah sebagai berikut.

Berpangkal dari Tuhan yang memikirkan substansi-Nya, timbul suatu wujud baru yang ke luar dari Tuhan yang disebut Akal Pertama (al-aqlul Awwal). Akal pertama ini kemudian ber-ta'aqul pula, memikirkan akal Tuhan dan memikirkan dirinya sendiri. Dengan ta'aqul, Tuhan melimpahkan Akal Kedua (al-Aqlusstami) dan ta'aqul sendiri menimbulkan langit yang paling luar beserta jiwanya ( al-falaq al-aqsha). Dari sejak inilah mulai sifat kejamakan dari alam (makhluk). Seterusnya dari Akal Kedua tibullah Akal Ketiga (Al-aqlusstalist) yang bersama langit kedua atau wakibistalist dengan cara yang sama seperti terjadinya pada akal pertama.

Dari Akal Ketiga muncullah Akal Keempat (al-Aqlurrbi) yang diserta planet saturnus bersama jiwanya (Zuhal) Kemudian dari Akal Keempat melimpah Akal Kelima (al-aqlulkhamis) dan planet zupiter dengan jiwanya ( al-musytari). Dari Akal Kelima melimpah Akal Keenam ( al-aqlussadis) yang bersama dengan planet mars serta jiwanya (mirrib). Lalu melimpah Akal Ketujuh (al-aqlussabi) dari Akal Keenam diserta matahari dengan jiwanya (as-syams). Dari Akal Ketujuh timbul Akal kedelapan

${ }^{23}$ Nasution, Harun., Falsafah dan Mistisisme dalam Islam, Jakarta Bulan Bintang, 1973 h. 26 
(al-aqlusstamin) bersama planet venus degan jiwanya (az-zubrab). Seterusnya dari Akal Kedelapan melimpahlah Akal Kesembilan (al-aqluttas') bersama pula planet merkerius dengan jiwanya (utharid).

Akhirnya Akal Kesembilan melimpahkan Akal Kesepuluh (al-aqlulasyir) atau aqlul fa'al beserta bulan (qamar) dengan jiwanya. Pada Akal Kesepuluh berhentilah melimpahnya atau timbulnya akal-akal tersebut. Tetapi dari Akal Kesepuluh ini keluarlah bumi serta roh-roh dan materi asal (materi pertama) yang menjadikan dasar dari keempat unsur yaitu api, udara, air dan $\operatorname{tanah}^{24}$ Pembicaraan teori emansi ini berpengaruh pada ajaran tentang Nur Muhammad yang di ajarkan Abah Pal Lima. Karena ajaran ini hanya menggunakan akal, sebagaimana juga yang di katakan Abah Pal Lima bahwa:

Jalan menuju Allah bukan lewat perantara nabi Mubammad melainkan akal yang dimiliki. Maka dari itu Alquran dan hadis adalah sumber ajaran yang tidak. penting bagi "orang batin" sebab mendapatkan sumber ajaran hanya dari akal. .

Ajaran Abah Pal Lima juga di pengaruhi faham wabdatul wujud ialah: karena merasa diri bagai kepompong dan isinya tak lain adalah Dia atau Allah itu sendiri, hal ini terungkap dari penjelasannya:

"Sifat Allah jangan dirampas, Hayat bidup Allah, Hayun bidup Allah, kita ini mati tidak bidup. Yang bidup itu banya Allah. Aku lebib nampak dari pada sifat-Ku. Inilah yang masuk ke dalam raga atau rangka. Allah itu wajib ada, wujud artinya ada, mustabil artinya tiada. Aku atan Zat masih asma. Yang benar adalah kita harus mati, yakni mati dalam bidup".

Lebih jauh diungkapkannya bahwa "jangan handak ke sorga, sebab bagi "orang batin" sorga tidak pernah benar adanya. Dan bagi "orang batin" dunia itupun tidak ada. Manusia berdiam di dunia sedangkan bagi kami "orang batin" berdiam di Alam. Dunia tidak pernah diciptakan Allah. Yang diciptakan hanya alam semesta (sekalian alam) dari nur zat-Ku juga. Ayat berkata: al-insanu fibi wasiri wa sifati wa gairihi, bermula insan itu rahasia-rahasiaKu, sifat-sifat-ku tidak lain dari pada Aku. Wafi anfu sikum afala tubsyirun : tidakah engkau memperbatikan Aku ada di dalam diri kamu".

Penjelasannya bahwa Allah berada dalam diri manusia dan alam semesta, ini menunjukkan pengaruh faham wahdat al-wujud. Wahdatut al-wujud (وحدة الوجود ) berarti kesatuan Wujud, unity of existence. Faham ini adalah lanjutan dari faham bulul, dan dibawa oleh Muhy al-Din Ibn Arabi yang lahir di Murcia, Spanyol, tahun 1165 M. Setelah selesai studi di Seville, ia pindah ke Tunis tahun 1194 dan di sana ia masuk aliran sufi. Pada tahun 1202 M. Ia pergi ke Mekah dan meninggal dunia di Damaskus tahun $1240 \mathrm{M}^{25}$.

Faham wahdat al-wujud ini merupakan perluasan dari paham Hulul adalah karena nasut yang ada dalam Hulul ia ganti dengan istilah khalq (makhluk), sedangkan Labut ia ubah menjadi al-Haqq (Tuhan). Khalq dan al-Haqq adalah dua sisi bagi segala sesuatu, yaitu sisi lahir dan sisi batin. Aspek lahir disebut Khalq memiliki sifat kemakhlukan atau kemanusiaan (nasut) dan aspek batinnya disebut al-Haqq memiliki sifat ketuhanan atau Labut. Tiap yang bergerak tidak lepas dari kedua aspek tersebut. Tetapi aspek yang terpenting adalah batinnya atau aspek al-Haqq dan ini merupakan esensi/hakikat dari tiap-tiap yang wujud.

${ }^{24}$ http://Vhocket.blogspot.com/2015/02/teori-emanasi-al-farabi-filsafat.html?m=1, di akses tanggal 07 November 2018

${ }^{25}$ Nasution, Harun, Op Cit., 92 
Konsep Wabdat al- Wujud ini juga dilatarbelakangi oleh pemikiran bahwa alam ini diciptakan Allah dari'ain wujudnya sehingga apabila Tuhan ingin melihat dirinya maka Ia cukup melihat alam ini yang pada hakikatnya tidak ada perbedaan antara keduanya. Dengan kata lain, walaupun alam ini tampaknya berbeda-beda tetapi pada tiap-tiap yang ada itu terdapat aspek ketuhanan, dan pada hakikatnya Tuhanlah yang menjadi esensi sesuatu itu. Dari sini lahirlah konsep atau paham Wabdat al- Wujud (kesatuan wujud), dengan pengertian bahwa alam yang nampak berbeda atau bervariasi ini sesungguhnya adalah satu, seperti orang yang melihat bayangannya di dalam beberapa cermin, berapapun banyaknya bayangan itu, namun orang hanya satu orang ${ }^{26}$.

Ajaran wahdat al-wujud di Kalimantan Selatan memang pernah berkembang mulai abad ke-17. Pada masa itu, seorang ahli tasawuf di kerajaan Banjar telah menyusun sebuah kitab ilmu tasawuf yang judul "Asal Kejadian Nur Muhammad", yang dipengaruhi oleh ajaran Ibnu Arabi yang termasuk aliran wabdat al-wujud. Kitab tasawuf itu dikarang oleh Syekh Ahmad Syamsuddin al-Banjari ${ }^{27}$.

Di sisi lain yang ada kaitan dengan tasawuf ini, bahwa ajaran Abah Pal Lima tidak mempercayai adanya wali Allah. Dalam agama Islam bila tidak percaya adanya wali Allah berarti tidak percaya kepada Alquran, sebab adanya wali Allah bersumber dari Alquran surat Yunus (10) ayat 62-63 yang berbunyi:

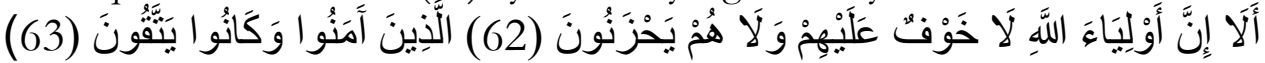

Orang-orang sufi berbeda pendapat apakah seorang wali dapat mengetahui dirinya sebagai wali atau tidak. Abu Bakar Faurik berkata bahwa seorang wali tidak akan mengetahui bahwa dirinya menjadi wali. Karena apabila ia melihat ada suatu perbuatan nampaknya ganjil yang terjadi pada dirinya, dia merasa takut kalau yang demikian itu termasuk perbuatan "makar" yang akan dapat memerosotkan nilai dirinya di sisi Tuhannya. Sedang Abu Ali Daqaq mengatakan bahwa seorang wali mungkin saja mengetahui dirinya sebagai wali apabila lahir tanda keramat pada dirinya, dengan adanya tanda itu, dia berusaha menghormati dan memelihara dengan sebaiknya.

Ibrahim bin Adham pernah bertanya kepada seseorang apakah ia ingin menjadi wali ?. Orang itu menjawab :Ya. Ibrahim berkata: Jangan kau menginginkan sedikit juapun baik dunia maupun akhirat, tetapi hadapkan jiwa ragamu kepada Allah, ikhlaskan amal perbuatanmu karena Allah, niscaya Allah memberikan pertolongan kepadamu dan memberikan perlindungan ${ }^{28}$. Seorang wali yang telah memperlihatkan keanehan dan keajaiban (keramat), sehingga mereka sering juga disebut sebagai orang suci. Keanehan itu bisa terjadi di saat masih hidup atau setelah meninggal dunia, dan bisa juga mereka hidup dan meninggal dunia dalam ketidakjelasan ${ }^{29}$.

Keramat merupakan aktivitas yang bertolak belakang dengan adat di saat-saat pemaksaan dan merupakan realiatas sifat kewalian tentang makna pembenaran dalam situasi (keadaan)nya. Al-Asfarayaini mengatakan," Para wali mempunyai keramat yang menyerupai keterkabulan doa". Memang seorang wali tidak sama dengan nabi dan rasul. Keduanya memiliki perberdaan yang amat jauh. Bila seorang nabi dan rasul

\footnotetext{
${ }^{26}$ Siregar, H.A. Riva, Op. Cit.,183-184

${ }^{27}$ Aizid, Rezem, Sejarah Islam Nusantara, Yogyakarta, Diva Press, 2016, 223

${ }^{28}$ Sjukur, Asjwadie,. Ilmu Tasawnuf II. PT. Bina Ilmu Surabaya 1979. H. 139-140

${ }^{29}$ Nicholson, Reynold A,. Mistik Dalam Islam, Jakarta, Bumi Aksara, Cet.II. 2000, 95
} 
langsung menyatakan kepada umat, bahwa dia telah diutus oleh Allah dan diberi-Nya wahyu untuk disampaikan kepada umatnya, akan tetapi seorang wali tidak akan pernah menyampaikan kepada siapapun, bahwa ia telah dipilih oleh Allah sebagai waliyullah,

Keramat yang diberikan kepada wali merupakan kemulyaan, tetapi yang dimaksud di sini ialah kejadian luar biasa yang terjadi atas seorang mukmin, tetapi keluarbiasaan itu tidaklah menyamai mukjizat para nabi dan rasul yang diperlihatkan Allah kepada umatnya. Keluarbiasaan bisa juga berupa doa-doanya yang dikabulkan, memiliki pengaruh yang besar,ilmu yang luas dan dalam, memiliki kecerdasan spiritual dan kecerdasan rasional, tetapi bisa juga bersifat fisik atau kejasmanian, misalnya terhindar dari bahaya, dapat menempuh perjalanan yang jauh dalam waktu yang relatif pendek dan lain sebagainya.

Keramat bisa terdapat pada para waliyullah sewaktu masih hidup ataupun sesudah meninggal dunia. Bahkan juga kekeramatan itu bisa disaksikan dan dibenarkan oleh orang di masa silam, sekarang dan akan datang. Bahkan imam Gazali menyatakan, bahwa siapa yang membantah adanya manusia tingkat wali, maka ia membantah adanya manusia tingkat nabi. Bahkan sekalipun nabi-nabi dan wali-wali itu adalah manusia seperti kita juga, tetapi qalbu mereka itu sangat luarbiasa bersihnya dan sucinya, sehingga dapat lekas menerima dan merasa segala sesuatu yang bersifat suci, bersih dari sifat yang tercela, dan dengan mudah menangkap atau menerima pancaran Nur apa-apa yang tertulis dalam Laubin Mabfuzd (suratan nasip). Orang yang telah sampai ketingkat tinggi itu, telah lulus dari ujian mujahadah sehingga sampai mendapat pangkat wali, dengan mempunyai kebesaran dan ketinggian martabat jiwa menghampiri nabi. Dapatlah melaksanakan pekerjaan-pekerjaan yang besar, karena jiwanya yang besar dengan izin Allah ${ }^{30}$.

Adapun keadaan yang dianggap luar biasa yang terjadi pada Abah Pal Lima seperti yang diungkapkan responden bahwa di saat dia ikut ziarah bersama rombongan abah Pal Lima, ke makam yang di anggap keramat, di antaranya makam Abdul Hamid Habulung di daerah Martapura. Semua penziarah menggunakan perahu kecil (jukung) menuju ke makam yang berada di seberang sungai, sementara Abah Pal Lima dilihat oleh pengikutnya menyebarangi sungai Martapura itu dengan berjalan kaki di atas air sungai menuju makam tersebut. Dan Abah Pal Lima mengatakan kepada pengikutnya bahwa datu Habulung menjemputnya dengan mengulurkan tangannya ke sungai ${ }^{31}$.

Keadaan sebenarnya bukan karamat yang dimiliki Abah Pal Lima ini, melainkan sebuah istidraj ( kesenangan dan nikmat yang Allah berikan kepada orang yang jauh dari-Nya). Sebab kehebatannya itu bukan hasil ibadah yang istqamah, dan malah dia tidak percaya kepada rukun iman dan rukun Islam termasuk tidak percaya kepada adanya wali Allah. Memang banyak orang tertarik kepadanya, sehingga menjadi pengikutnya, karena adanya kehebatannya itu, ditambah lagi dia melakukan praktik pengobatan alternatif, yang sekaligus menyampakan ajarannya yang berupa ajaran sempalan.

Islam adalah sebuah agama memungkinkan munculnya berbagai aliran dan paham keagamaan, karena agama ini memberikan kebebasan kepada pemeluknya

${ }^{30}$ Zahri, Mustafa,. Kunci Memahami Ilmu Tasawwuf, PT. Bina Ilmu Surabaya 1979, 117.

${ }^{31}$ Wawancara dengan HAL., tanggal 05 Agustus 2018 
untuk menafsirkan dan memahami teks-teks keagamaan sepanjang mereka memiliki ilmu untuk melakukan hal tersebut. Justru itu tidak ada tafsir tunggal dalam masalah agama. Hanya saja bila penafsiran itu dilakukan oleh mereka yang tidak mempunyai kemampuan untuk melakukan hal itu, maka sudah tentu penafsirannya tidak sesuai dengan kaidah-kaidah yang telah disepakati bersama oleh para mujtahid. Bila itu terjadi maka akan bermunculan protes dari para pemuka agama, karena ajaran yang dikembangkan tersebut dianggap menyimpang dan sesat ${ }^{32}$.

Ajaran yang menyimpang inilah yang dikenal degan istilah gerakan sempalan atau aliran sempalan. Istilah "sempal" dari bahasa Jawa artinya patah, terpisah dahan dari batang pohon, atau cabang dari dahan. Istilah "sempal/gerakan sempalan itu terwujud bila seorang pemimpin yang berani melakukan koreksi total atas dirinya sendiri dan diri anggota kelompoknya dan penataan kembali kehidupan kelompok secara menyeluruh.

Untuk mengetahui apakah aliran/gerakan sempalan termasuk jalan yang dtunjuki dan diridai Allah atau bukan, maka perlulah adanya pengkajian yang seksama. Munculnya aliran/gerakan sempalan di Indonesia secara umum, bukan karena agama tidak mampu dalam mengatur dan membahagiakan umat manusia, akan tetapi karena beberapa faktor, antar lain:

a. Kejahilan dan kebekuan hati yang tidak mampu menerima petunjuk Allah yang benar, sehingga apa yang sebenarnya baik dianggap tidak baik, dan apa yang benar dianggap salah. Agama yang merupakan ajaran dari Allah dianggap kurang sempurna, sehingga perlu disempurnakan dengan hasil penemuan sendiri.

b. Fanatisme yang kuat terhadap naluri dan leluri leluhur, sehingga dengan sikap tersebut dapat menutup kebaikan dan kebenaran yang datang dari luar dan menganggap apa yang datang dari luar itu sebagai penjajahan terhadap warisan leluhur.

c. Pencetusan sikap hidup yang serba magis mistis yang diwariskan para leluhur, dan ada keinginan yang kuat untuk menghidupkan warisan leluhur itu, tanpa memandang benar atau tidaknya menurut pandangan agama.

d. Adanya pandangan satu sisi terhadap agama, tidak secara keseluruhan, atau hanya memandang agama dari kejauhan tidak secara dekat, ditambah lagi adanya rasa ketidak puasan terhadap agama. Kuatir kalau agama mendesak warisan leluhur.

e. Adanya umat Islam dan para juru dakwah yang ceramahnya lebih mengutakan lahiriyah ajaran agamanya dan kurang memperhatikan soal kepuasan kehidupan batinyah.

f. Kurang pendekatan secara pribadi para juru dakwah terhadap golongan aliran/gerakan sempalan atau aliran kepercayaan, dan kurang beraneka ragamnya metode dakwah yang dipergunakan untuk menyebarkan agama Islam.

g. Pemunculan aliran/gerakan sepalan atau aliran kepercayaan lainnya memang sudah dikehendaki Allah sebagai pertimbangan dari yang haq dan agar seeorang bisa membandingkan antara keduanya, sehingga umat Islam dapat berjuang menegakkan agamanya dan memperoleh pahala dari apa yang diusahakan. Jika

${ }^{32}$ Badan Litbang dan Dklat kementerian Agama, Aliran-alran Keagamaan Aktual di Indonesia, (Jakarta: Maloho Jaya, Abadi Press, 2010), vii 
Allah menghendaki tentu manusia seluruh dunia akan beriman semuanya, seorang Islam tidak bisa memaksa mereka untuk beriman, melainkan hanya menyampaikan yang haq saja $^{33}$

h. Salah terima dari guru, dan karena lemahnya pengetahuan tentang bahasa Arab yang merupakan hal yang penting dalam memahami agama Islam .

i. Ingin mementingkan rasa atau pengalaman rohani, dari pada hal-hal yang berbau lahir.

\section{Ajaran Tentang Akidah dan Ibadah}

Dalam ajaran Abah Pal Lima mengakui adanya Allah swt., yang memiliki sifatsifat, di antaranya sebagaimana diungkapkannya "Kita Percaya babwa qodrab kuasa Allah, iradat kehendak. Allah, Ilmu, ilmunya Allah, hayat bidupnya Allah, Sama' mendengar Allah, rasa melihat Allah, kalam, kata-kata Allah. Tidak ada yang kita miliki disitu". Sebenarnya sifat-sifat Allah ini banyak sebagaimana disebutkan oleh imam As Sanusi di dalam kitabnya Ummul al-Barahin, disebutkan bahwa Allah Ta'ala memiliki sekurangnya 20 sifat yang wajib dan 20 sifat yang mustahil dan satu yang jair (harus). Dan sifat-sifat Allah tersebut dkelompokkan kepada empat bagian yaitu Nafsiyah, Salbiyah, Ma'ani dan Ma'nawiyah.

Sifat Nafsiyah dimaksudkan sebagai sifat Zat, bukan tambahan bagi Zat. Sifat Nafsiyah hanya satu yaitu Wujud yang artinya ada. Sifat Salbiyah adalah sifat yang ada pada Zat Allah yang menolak semua sifat yang tidak layak bagi keagungan atau kebesaran Allah swt. Sifat Salbiyah ini ada lima sifat, yaitu Qidam (tidak berawal), Baqa (tidak berakhir), Mukhalafatubu lil hawadits (berbeda dari semua baharu), Qiyamubu bi nafsib (berdiri dengan sendirinya), $W$ abdniyat (esa atau tunggal). Sifat $M a$ 'ani yaitu sifatsifat yang menambah makna kesempurnaan bagi Zat Allah swt. Yang termasuk sifat Ma'ani ada tujuh yaitu Qudrat ( kuasa), Iradat (berkehendak), Ilmu (mengetahui), Hayat (hidup), Sama' mendengar), Bashar (melihat), dan Kalam (berkata-kata).

Selanjutnya sifat Ma'nawiyah merupakan sifat-sifat yang keberadaannya disebabkan oleh adanya sifat Ma'ani. Karenanya maka sifat-sifat Ma'nawiyah adalah sifat-sifat yang melazimkan atau menunjukkan kepada Zat pemilik sifat Ma'ani. Karena sifat Ma'ani ada tujuh, maka yang termasuk sifat Ma'nawiyahpun juga tujuh sifat yaitu Qadirun (Yang Maha berkuasa), Muridun (Yang Maha Berkehendak), 'Alimun (Yang Maha Mengetahui), Hayyun (Yang Maha Hidup), Sami'un (Yang Maha Mendengar), Bashirun (Yang Maha Melihat), Mutakallimun (Yang Maha Berkata-kata) ${ }^{34}$

Walaupun dia mengakui keberadaan Allah dengan segala sifat-sifat-Nya, namun dia tidak mengakui terhadap rukun iman dan rukun Islam hal ini telah diunkapkannya setelah terjadi dioalog dengan Sugi yang telah bertapa dalam kubur selama 21 hari dan ditemui seorang makhluk gaib yang mengatakan kepada Sugi bahwa rukun iman dan rukun Islam itu tidak benar adanya. Semua ulama yang ditemui Sugi mengatakan, bahwa Sugi membawa ajaran sesat, sementara Abah Pal Lima memiliki pemahaman yang sama dengan Sugi itu. Abah Pal Lima yang juga mengatakan "bahwa rukun iman dan rukun Islam itu tidak ada”. Karena dia tidak percaya kepada adanya rukun iman dan rukun Islam, sehingga dia dan pengikutnya, tidak mengakui keberadaan malaikat, rasul, kitab suci, hari kiamat dan tidak melaksanakan salat, puasa, zakat dan haji.

${ }^{33} \mathrm{Abdul}$ Muthollib Ilyas dan Abd. Ghofur Imam, Aliran Kepercayaan dan Kebatinan di Indonesia, (Surabaya, CV. Amin, 1988), 178

${ }^{34}$ Hatta, Mawardy, Ibid, 67-69 
Orang yang percaya dan melaksanakan rukun iman dan rukun Islam adalah orang yang beragama Islam dengan sempurna. Sebab Islam adalah agama yang berintikan iman dan amal. Iman mencerminkan akidah dan pokok-pokok (ushul) agama yang menjadi landasan bagi syari'at Islam. Dari dasar-dasar ini lahirlah kemudian cabang-cabangnya (furu). Amal mencerminkan syari'ah dan cabang-cabang yang merupakan tindak lanjut dari iman dan akidah ${ }^{35}$

Iman dan amal atau akidah dan syariah selalu berkaitan satu sama lain bagaikan keterkaitan antara buah dengan pohon. atau antara akibat dengan sebab. Karena keterkaitan inilah maka penyebutan amal sering dirangkai dengan penyebutan iman pada banyak ayat Alquran, seperti pada surah al-Baqarah ayat 25:

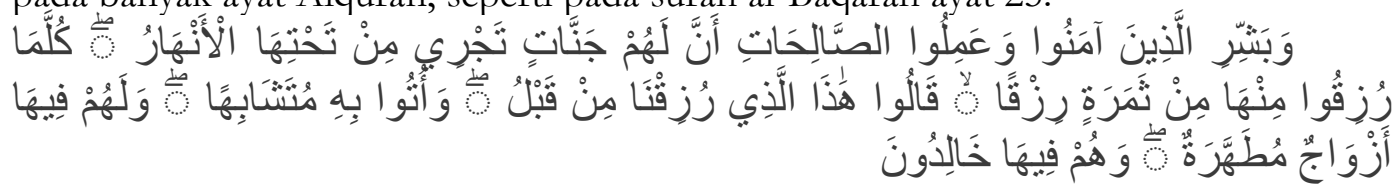

Pada surah Maryam ayat 96 Allah juga menegaskan:

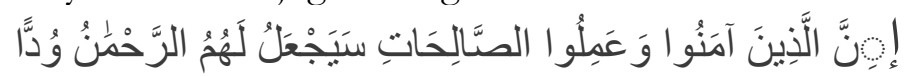

Dalam ayat Alquran di atas disebutkan bahwa penyebutan orang beriman dirangkai dengan penyebutan amal saleh. Ini mencerminkan betapa eratnya hubungan antara iman dengan amal saleh. Ini juga dapat dipahami bahwa setiap mukmin atau orang beriman hendaknya beramal saleh, dan setiap orang yang beramal saleh hendaknya beriman.

Bagi mereka yang menganut suatu ajaran, termasuk ajaran Abah Pal Lima, dan dalam ajaran itu tidak percaya kepada salah satu saja dari rukun iman atau rukun Islam, maka ajaran tersebut di anggap sesat. Hal ini sesuai dengan keputusan Majelis Ulama Indonesia yang menyebutkan ada 10 macam kriteria aliran sesat yaitu:

1. Mengingkari salah satu rukun iman yang enam.

2. Meyakini dan atau mengikuti akidah yang tidak sesuai dengan Alquran dan

3. Sunnah

4. Meyakini turunnya wahyu sesudah Alquran.

5. Mengingkari otentisitas dan atau kebenaran isi Alquran.

6. Melakukan penafsiran Alquran yang tidak berdasarkan kaidah-kaidah tafsir.

7. Mengingkari kedudukan hadis nabi sebagai sumber ajaran Islam.

8. Menghina, melecehkan atau merendahkan nabi dan rasul terakhir.

9. Mengingkari Nabi Muhammad sebagai nabi dan rasul terakhir.

10. Mengubah, menambah dan atau mengurangi pokok-pokok ibadah yang telah ditetapkan oleh syar'iah, seperti haji tidak kebaitullah, salat wajib tidak 5 waktu.

11. Mengafirkan sesama muslim tanpa dalil syar'i seperti mengkafirkan hanya kerena buka kelompoknya ${ }^{36}$

Bila salah satu saja dari yang sepuluh kriteria tersebut, terdapat dalam sebuah ajaran baru, maka ajaran tersebut sudah termasuk aliran sesat yang perlu diwaspadai dan ditindaklanjuti oleh instansi terkait.

${ }^{35}$ Sabiq, Sayyid, Aqidah Islam, (terjemahan dari al-Aqidat al-Islamiyah oleh Ali Ahmadi), Jakarta, Rabbani Press 1992, 3

3610 Kriteria Aliran Sesat Menurut MUI. 
Sehubungan aliran yang diajarkan Abah Pal Lima ini tidak mempercayai kepada rukun iman dan rukun Islam, maka ajaran Abah Pal Lima ini dianggap sesat. Hal ini sesuai dengan hasil rumusan kajian Komisi Fatwa dan Komisi Pengkajian dan Penelitian MUI Kota Banjarmasin, pada tanggal 06 November 2017 setelah mendengari berbagai laporan, baik dari Ketua RT, Lurah, Intel Polisi, penyuluh Agama, ulama dan tokoh masyarakat sehingga MUI kota Banjarmasin berkesimpulan bahwa ajaran tersebut tergolong Ajaran Sesat, karena mengajarkan syahadat yang lain dan Alquran tidak mereka pakai. Selain itu mereka tidak melaksanakan salat wajib termasuk salat Jumat, dan pengkutnya yang laki-laki boleh menggauli isteri orang lain, serta muridnya yang telah meninggal dunia, maka jenazahnya tidak boleh dimandikan. Dan selain dari pengikut ajarannya dianggap sesat atau masuk neraka.

Sehubungan ajaran abah Pal Lima ini tidak mengakui keberadaan Nabi Muhammad saw., sebagai rasul Allah hal ini terlihat dari pejelasannya:

"Jalan menuju Allah bukan lewat perantara nabi Mubammad melainkan akal yang dimiliki. Maka dari itu Alquran dan hadis adalah sumber ajaran yang tidak penting bagi "orang batin" sebab mendapatkan sumber ajaran hanya dari akal".

Mempercayai adanya nabi Muhammad saw., dan Alquran sebagai wahyu yang diturunkan Allah kepadanya, merupakan bagian dari rukun iman yang wajib dipercayai oleh setiap muslim.

Beriman kepada rasul-rasul, sebagai rukun iman keempat, yakni meyakini adanya rasul-rasul yang pernah diutus Allah swt., ke tengah umat manusia untuk menyampaikan agama yang benar, berasaskan akidah tauhid. Dan para rasul tersebut adalah manusia-manusia pilihan yang terpelihara dari dosa (ma'shum).

Jumlah rasul dan nabi tidak ada yang mengetahui secara pasti, karena Allah tidak menjelaskan tentang hal ini. Namun demikian, berdasarkan sebuah hadits yang bersumber dari Abu Zar al-Ghifari bahwa jumlah rasul sekitar 313 orang, dan jumlah nabi 124.000 orang.

Sekalipun jumlah nabi dan rasul itu banyak, namun yang wajib diimani atau dipercayai hanya 25 orang rasul sesuai dengan apa yang tersebut di dalam Alquran. Mereka adalah Adam, Idris, Nuh, Hud, Saleh, Ibrahim, Luth, Isma’il, Ishaq, Ya'qub, Yusuf, Ayyub, Syu'aib, Musa, Harun, Zulkifli, Daud, Sulaiman, Ilyas, Ilyasa', Yunus, Zakariya, Yahya, Isa dan Muhammad saw. Lima dari rasul-rasul itu disebut sebagai Ulul 'Azhmi artinya rasul-rasul yang mempunyai kesabaran dan keteguhan hati dalam memperjuangkan agama Allah ${ }^{37}$.

Rasululullah sebagai utusan Allah yang bertugas menyebarkan agama yang benar, maka untuk membuktikan kebenaran ajaran yang mereka dakwahkan, kepada manusia, rasul-rasul itu diberikan keistimewaan khusus oleh Allah swt., berupa mukjizat yakni kejadian luar biasa yang hanya diberikan kepada para rasul tersebut.

Salah satu mukjizar Nabi Muhammad saw., adalah Alquran, yang merupakan wahyu dari Allah swt., kepada Rasulullah saw. Beriman kepada kitab-kitab yang telah diturunkan Allah, yakni meyakini bahwa Allah telah menurunkan kitab-kitab kepada sejumlah nabi dan rasul, namun tidak dijelaskan jumlah kitab tersebut kecuali empat kitab yaitu kitab Taurat yang diturunkan kepada nabi Musa, kitab Zabur diturunkan kepada nabi Daud, kitab Injil diturunkan kepada nabi Isa, dan terakhir kitab suci

${ }^{37}$ Hatta, Mawardy, Op. Cit, 154 
Alquran diturunkan kepada nabi besar Muhammad saw. Selain itu, ada pula shubufshubuf yang diturunkan kepada nabi Musa dan nabi Ibrahim ${ }^{38}$.

Bila seseorang tidak percaya kepada Nabi dan rasul serta kitab-kitab yang diturunkan kepada mereka berarti orang tersebut tidak bisa dikatakan seorang yang mukmin. Sehubungan hal tersebut di atas, Abah Pa Lima masih mengaku seorang Islam, namun ternyata dia mengingkari kepada Nabi Muhammad dan wahyu yang Allah turunkan kepadanya. Karena ajarannya tidak mewajibkan salat, puasa, zakat dan haji. Bila seseorang mengaku beragama Islam, maka diwajibkan melaksanakan rukun Islam itu. Dalam rangka mengabdikan diri kepada Allah, maka Allah swt. melalui rasulullah saw., telah menetapkan lima kegiatan pokok peribadatan yang lazim disebut dengan rukun Islam itu, yaitu mengucapkan syahadat, mendirikan salat, menunaikan zakat, melaksanakan puasa Ramadhan, dan menunaikan ibadah haji.

Ibadah salat merupakan ibadah yang wajib dikerjakan oleh setiap muslim yang aqil baligh. Kewajiban salat ini banyak ditegaskan di dalam Alquran, antara lain pada surah surah an-Nisa ayat 103 :

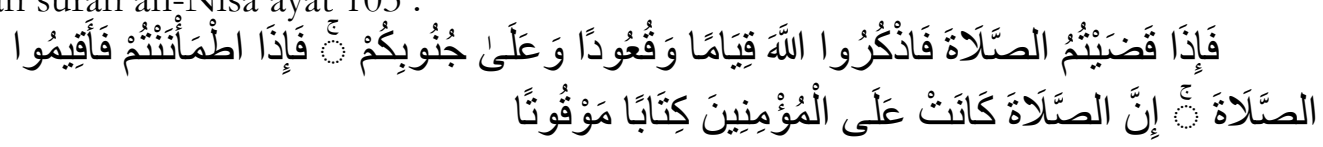

Salat itu ada yang bersifat wajib, dan ada pula yang bersifat sunat. Salat wajib atau fardu, yaitu salat Subuh, salat Zuhur, salat 'Ashar, salat Maghrib dan salat Isya. Sedangkan salat sunat, ada yang disebut salat sunat rawatib yakni salat sunat yang mengikuti salat fardu, dan ada pula salat sunat di luar dari salat fardu seperti salat Dhuha, salat Tahajjud, salat Hajat, salat Gerhana, salat Istikharah, salat Tarawih, salat Witir dan salat sunat Muthlaq ${ }^{39}$.

Ibadah salat ini tentu berbeda dengan ibadah lainnya seperti menunaikan zakat, puasa dan naik haji. Zakat dan puasa hanya diwajibkan sekali dalam setahun. Melaksanakan badah haji hanya diwajibkan sekali dalam seumur hidup. Sementara ibadah salat diwajibkan mendirikannya lima kali dalam sehari semalam. Ini berarti salat merupakan ibadah utama bagi setiap muslim, dan oleh rasulullah dikatakan sebagai tiang agama. Beliau menyatakan "Salat adalah tiang agama, siapa yang mendirikannya maka ia mendirikan agamanya, dan siapa yang meninggalkannya maka ia meruntubkan agamanya". (H.R. Bukhari).

Sementara Abah Pal Lima dan pengikutnya meninggalkan salat, maka ini berarti mereka telah meruntuhkan agama. Dia tidak melaksanakan salat dan ibadah lainnya seperti puasa zakat dan haji karena menganggap diri mereka mati bukan hidup sebangaimana ungkapannya bahwa" jika orang melakukan ibadab seperti salat, puasa, baji dan lainnya, maka dia akan mendapat ganjaran hangus terbakar ketika di kubur, alasanya dia mengatakan: "kalau ditelaah kata "tidak ada daya dan upaya" bagi manusia melainkan kuasa Tuban, lantas kalau manusia tidak ada daya dan upaya maka pantaskah Tuban yang Maha Kuasa memerintabkan salat, zakat, haji, kepada kita, tentu tidak pantas dan tidak adil bagi Tuhan"

Lebih jauh Abah Pal Lima menjelaskan bahwa kami sebagai "orang batin" sebenarnya kami adalah mati, sebab kalau masih mengaku hidup dan Allah itu hidup, berarti ada dua yang hidup, maka hukumnya syirik. Sebenarnarnya istilah syirik (aslinya: Syirkun), yang menurut arti bahasa persekutuan, bagian. Sedangkan menurut

${ }^{38}$ Razak, KH. Nasruddin, Dienul Islam, Bandung, PT. Al-Ma'rif, 2012, 197.

${ }^{39}$ Rasyid, Sulaiman, Fiqh Islam, Bandung, Sinar Baru Algesindo, 2014, 144- 152 
istilah agama berarti: "Mempersekutukan Allah dengan lainnya". Ada yang megatakan, bahwa syirik artinya kufur, di samping itu ada pula yang mengatakan bahwa syirik adalah satu dia antara macam-macam kekufuran.

Syirik bila ditinjau dari segi besarnya nilai dosanya maka dibagi kepada dua yaitu: 1. Syirik besar (Asy syirkul "azhim), yaitu mempercayai/menetapkan adanya sekutu bagi Allah. 2. Syirik kecil (Asy Syirkus shaghiir), yaitu adanya perhatian selain Allah dalam beramal ibadah, yang biasa disebut riya'. Seperti mengharap pujian, materi atau lainnya dalam beribadah ${ }^{40}$.

Rasulullah saw bersabda:

\section{Simpulan.}

$$
\text { ان اخوف ما اخاف عليكم الشرك الأصغر - الرياء. }
$$

Aliran Sempalan yang diajarkan Abah Pal Liman masih mempercayai adanya Allah swt., yang Maha Esa, yang memiliki berbagai sifat, namun tidak mempercayai adanya rukun iman dan rukun Islam. Sehingga tidak percaya kepada adanya malaikat, rasul, kitab suci (Alquran) serta masalah taqdir dan tidak ada kewajiban untuk mengakui syahadat serta tidak laksanakan salat, puasa, zakat dan haji. Dia beranggapan selain dia dan pengikutnya dipandang sesat dan akan masuk neraka.

Ajaran ini mengutamakan masalah batin, dan beranggapan bahwa mereka adalah "orang batin" yang berada di "alam" bukan orang "lahir yang berada di "dunia". Orang batin merasa dirinya mati, kalau merasa hidup adalah syirik, sebab menurutnya bila mengaku hidup, maka berarti ada dua yang hidup, yaitu Allah dan yang merasa hidup itu. Karena menganggap diri mati, maka tidak adil Allah kalau memerintahkan wajib salat, puasa, zakat dan haji kepada orang yang mati. Inilah alasan mereka sehingga tidak melaksanakan kewajiban itu.

Ajaran Abah Pal Lima ini sangat dipengaruhi oleh wabdat al-wujud (kesatuan wujud) yang dikembangkan oleh Ibnu Arabi, karena membicarakan masalah nur Muhammad dan pada manusia ada unsur ketuhanan selain adanya unsur kemakhlukkan (al-Haq dan al-Khalq). Juga dipengaruhi oleh ajaran al-Farabi yang berkenaan dengan teori emanasi atau pelimpahan.

Ajaran Abah Pal Lima ini sudah divonis sesat oleh Majelis Ulama Indonesia Kota Banjarmasin, tanggal 06 Jumadil Awwal 1439 H. / 23 Januari 2018 M. dengan nomor surat. 004/DPK-MUI/Bjm/1/I/2018, karena isi ajarannya sesuai dengan sepuluh kriteria aliran sesat menurut MUI.

\section{Daftar Pustaka}

A. Manan, Imran, (1998). Pelbagai Masalab Taubid Populer, Jilid I, Surabaya, PT. Bina Ilmu.

Aizid, Rezem, (2016). Sejarah Islam Nusantara, Yogyakarta, Diva Press.

Amin, Ma'ruf dkk., (2011). Hinupunan Fatwa MUI Sejak 1975, Jakarta: MUI

Asmaran, (1994). Pengantar Studi Tasawuf, Jakarrta, PT. Raja Grafino persada.

Badan Litbang dan Diklat Kementerian agama RI, (2010) Aliran-aliran Keagamaan Aktual di Indonesia, Jakarta: Maloho Jaya Abadi Press.

El Hafidy, M. As'ad, Aliran-aliran Kepercayaan dan Kebatinan di Indonesia, Jakarta, Ghalia Indonesia.

Hubaisy, Thaha Dasuki, (2006). Munculnya Aliran-aliran Sesat di Abad Modern, Jabar:

${ }^{40}$ A., Manan, Imran, Pelbagai Masalab Taubid Populer, Jilid I, Surabaya, PT. Bina Ilmu 198, 30 
CV. Pustaka Setia.

Ilyas, Abdul Muthalib \& Abd. Ghofur Imam, (1088). Aliran Kepercayaan dan Kebatinan di Indonesia, Surabaya: cv. Amin.

Ismail, Faisal, (2014). Dinamika Kerukunan Antar umat Beragam, Bandung: PT. Remaja Rosdakarya Offiet.

Jami, M. Mukhsin, (2008). Agama-agama Baru di Indonesia, Yogyakarta: Pustaka Pelajar.

Khadziq, (2009). Islam dan Budaya Lokal, Yogyakarta: Teras.

Mansur, H.M. Laily, (1992). Tasawnf Islam, Mengenal Aliran dan Ajaran, Banjarmasin, Lambung Mangkurat Univrsity Prss.

M. Sufaat, Beberapa Pembahasan Tentang Kebatinan, Yogyakarta: Kota

Nata, Abuddin, (1993). Ilmu Kalam, Filsafat, dan Tasawnf, Jakarta, Rajawali Press.

Nasution, Harun., (1973). Falsafah dan Mistisisme dalam Islam, Jakarta Bulan Bintang.

Rasyid, H. Sulaiman, (2014). Figh Islam, Bandung, Sinar Baru Algesindo.

Razak, K.H. Nasruddin, (2012). Dienul Islam, Bandung, PT. Al -Ma'arif,

Siregar, H.A. Rivay, (1999). Tasawuf dari Sufisme Klasike Ke Neo-Sufisme, Jakarta, PT.

Raja Grafindo Persada.

Sofwan, Ridin, (1999). Menguak Seluk beluk Aliran Kebatinan, Semarang: Aneka Ilmu

Subagya, Rahmat, (1992). Kepercayaan, Kebatinan, Kerohanian Kejiwaan dan Agama, Yogyakarta: Kanisius,

Sjukur, Asjwadie, (1979). Ilmu Tasawnuf II. PT. Bina Ilmu Surabaya.

Zahri, Mustafa, (1979). Kunci Memahami Ilmu Tasawnuf, PT. Bina Ilmu Surabaya 